\title{
Laparoscopy Assisted Management of Urachal Anomalies In Children; A Relief for The Surgeon and the Patient?
}

\author{
Beytullah Yağız' iD
}

${ }^{1}$ Ondokuz Mayız University Medical Faculty Department of Pediatric Surgery Division of Pediatric Urology

Beytullah YAĞIZ

Correspondence: Beytullah Yağız Ondokuz Mayız University Medical Faculty Department of Pediatric Surgery Division of Pediatric Urology

Phone: +905336587502

E-mail: beytullahyagiz@gmail.com

\begin{abstract}
Introduction: Anomalies of the urachus constitute a challenge for the physcian and a source of anxiety for the parents. As the significance of the condition and borders between normal and abnormal are not clear, management is controversial. Although not universal, common indications for surgery are presence of symptoms (infection, pain etc) and fear of malignant transformation.

Materials And Methods: The children who underwent a laparoscopic surgery for a condition related to urachal remnants between 2007 and 2019 are enrolled in the study. Demographics of the patients, intraoperative complications and histological results were retrospectively evaluated and surgical procedure is described.

Results: A total 13 patients were included in the study. Seven patients had urachal cyst (53\%),3 had urachal sinus (23\%), 1 patent urachus (8\%), 1 omphalomesenteric band remnant (8\%) and could not be classified in $1(8 \%)$. Three ports were employed in 6 patients, 4 ports in 4 and 1 port in 2 and 2 ports in 1.Peritoneal contamination could not be avoided in 1 patient with infected urachal cyst during the operation, but postoperative course was uneventful in this patient.

Conclusion: Although surgical excision is the most commonly recommended management modality for urachal remnants, both parents and physicians hesitate due to the mysterious nature and insufficient data about the long term consequences of the condition. Choosing the best incision is also an issue and physicians may regret for any of the incisions as they may be 'too extensive' or 'insufficient'. Laparoscopic approach provides satisfactory identification of the condition, superior exposure and cosmesis, and at the worst scenario, a chance to select the most appropriate incision.
\end{abstract}

Keywords: Urachus, Remnant, Laparoscopy, Child, Surgery

\section{Çocuklarda Urakal Anomalileri Laparoskopik Tedavisi: Hem Cerrah Hem Hasta İçin Kolaylık Sağlayabilir mi?}

Giriş: Urakus anomalileri, hekimler için pek çok yönden zorlayıı, aileler içinde kaygı verici durumlardır. Anomalinin önemi ve normal ile anormal durumlar arasındaki sınırların net olmamasından dolayı tedavi yaklaşımları tartışmalıdır. Evrensel olmasa da, temel cerrahi endikasyonları semptom varlığı (enfeksiyon, ağrı vb) ve malignite gelişme korkusudur.

Gereç ve Yöntemler: Urakal kalıntılar ile ilgili bir durumdan dolayı 2007 ile 2019 yılları arasında laparoskopik cerrahi uygulanmaış hastalar çalışmaya dahil edildi. Hasta demografikleri, cerrahi sırasındaki komplikasyonlar ve histolojik inceleme sonuçları geriye dönük olarak incelendi ve cerrahi yaklaşımımız tariflendi.

Bulgular: Çalışmaya toplam 13 hasta dahil edildi. Yedi hastada urakal kist (\%53), 3 hastada urakal sinüs (\%23), 1 hastada patent urakus (\%8), 1 hastada omfalomezenterik kanal artığı (\%) bulunurken 1 hastanın patolojisi belirsiz (\%8) olarak tanımlandı. Altı hastada 3 port, 4 hastada 4 port, 2 hastada tek port ve 1 hastada da 2 port kullanıldı. Enfekte urakal kisti olan bir hastada cerrahi esnasında peritoneal kontaminasyon gelişmekle birlikte, cerrahi sonrası süreç sorunsuz geçti.

Sonuç: Her ne kadar urakal kalıntıların tedavisinde cerrahi eksizyon en sık kullanılan yöntem olsa da, hem hekimler hem de hastalar, bu patolojilerin doğasının belirsiz olması ve uzun dönem sonuçları hakkında yetersiz bilgi olmasından dolayı kararsız kalabilmektedirler. En uygun insizyonun seçimi de önemli bir meseledir ve hekimler tercih ettikleri insizyonun 'gereksiz büyük' yada 'yetersiz' olabilmesinden dolayı pişman olabilmektedirler. Laparoskopik yaklaşım, patolojinin tatminkar şekilde ortaya konmasını, cerrahi alana daha hakim olunabilmesini, ve en kötü senaryoda, en uygun insizyonu seçilmesine olanak sağlamaktadır.

Anahtar sözcükler: Urakus, Kalıntı, Laparoskopi, Çocuk, Cerrahi 
U rachal remnant anomalies are rare and heterogenous conditions in children and their clinical significance is a major source of confusion. As a result, rationals of management and indications for surgery are controversial. Common indications for surgery are persistent discharge, infection, urachal diverticulum and potential for malignant transformation. Moreover,as the margins of the anomaly are not clear on imaging studies in a significant proportion of patients, the extent of the exploration and excision is decided during surgery. Although theoretical classification of urachal anomalies is quite clear, it is pretty hard to fit a condition into these classes in daily practice as radiological and clinical findings are usually inconclusive. In this retrospective study, our aim is to evaluate our results of the laparoscopic management of urachal anomalies and describe our laparoscopic approach.

\section{MATERIALS AND METHODS}

The patients who underwent a laparoscopic or laparoscopy-asisted surgery for an urachal condition between 2007 and 2019 are enrolled in the study. The patients who were operated by pure open surgery were excluded. The admitting symptoms, histological results, age at surgery and complications were retrospectively evaluated. Main principles and extraordinary surgical details are described.

Institutional ethical board approval board was obtained for the study ( Ondokuz Mayıs University Ethical Board For Clinical Studies Approval No:2020/502)

\section{RESULTS}

A total of 13 patients were eligible for evaluation. Six (46\%) were boys and 7 (\%54) were girls. The admitting symptoms were abdominal pain $(n=6)$, umbilical discharge $(n=3)$, vomiting (incarcerated umbilical hernia) $(n=1)$, umbilical polip $(n=1)$ while 2 patients were diagnosed incidentally (1 during laparoscopy for acute abdomen and the other during follow up of Wilson's disease). Three ports were employed in 6 patients, 4 ports in 4 and 1 port in 2 and 2 ports in 1 . Seven patients had urachal cyst (53\%) (3 infected), 3 had urachal sinus (23\%), 1 had patent urachus (8\%) and 1 had omphalomesenteric band remnant (8\%). The condition could not be classified satisfactorily as radiological, surgical and histological findings were not coherent in 1 patient (8\%). Median age of the patients were 7.7 years (range; 0.3-15.3 years). Six of the patients had infection and 3 received at least 1 cycle of antibiotics before the surgery. Periton was contaminated by the infected content in 1 patient but postoperative process was uneventful in this patient. Peritoneal contamination could be avoided during surgery in 2 patients with an infected condition (Figure 1). In 1 patient, the urachal abscess was drained by a periumbilical incison under laparoscopic guidance to confirm the diagnosis and to assure the avoidance of peritoneal contamination. Histological examinations revealed urothelial epithelium in 7 patients, nonspecific fibromuscular tissue in 4, chronic inflammation in 1 and mucinous glands in 1. No malignancy was observed in any of the patients. Median follow up duration was 1 month (range; 1-39 months).

\section{Surgical Technique}

Insertion of the first port is an important step of the procedure. We prefer a 'crying face' incision located at the superior border of the umbilicus for the first port with an open technique when area of interest is away from umbilicus (urachal cyst, urachal diverticulum etc.). If area of interest is close to umbilicus (urachal sinus, patent urachus etc.), first port is introduced from the Palmer's point (on the left upper quadrant) by an open technique in order to obtain a wide angle vision. One can also use this site for the second port after insertion of the umbilical port if umbilical port is deemed inappropriate for the vision of the area of interest. The other working ports can be inserted parallel to the midline at the left of abdomen pointing the course of the urachus (Figure 2). When the margins of the anomaly is satisfactorily clear, limited resection is performed, but wide resection with inclusion of the medial ligaments and umbilicus is preferred if the margins are considered as 'not clear'. In 1 infant presented with umbilical polyp and patent urachus, 1 port was inserted through the Palmer's point and, the umbilical polyp and the patent urachus could be removed through a mini-periumbilical incision with the help of distending the bladder. In another patient who was presented as an incarcerated umbilical hernia, purulent discharge was encountered after umbilical incision was performed and the definitive diagnosis became evident as 'infected urachal cyst' (Figure 1). A single port for the camera was inserted from the left of abdomen and peritoneal violation and contamination were excluded by laparoscopic vision. The abscess was drained through the umbilical incision and managed with antibiotics. During the 13 months of follow up, no other intervention was deemed necessary as radiological and clinical findings suggest remission. In a third infant presented with a vague umbilical discharge, laparoscopic exploration was performed as ultrasonographic evaluation suggested a patent urachus containing air within. After insertion of the camera through the Palmer's point, no patent urachus was identified but a patent omphalomesenteric band was 


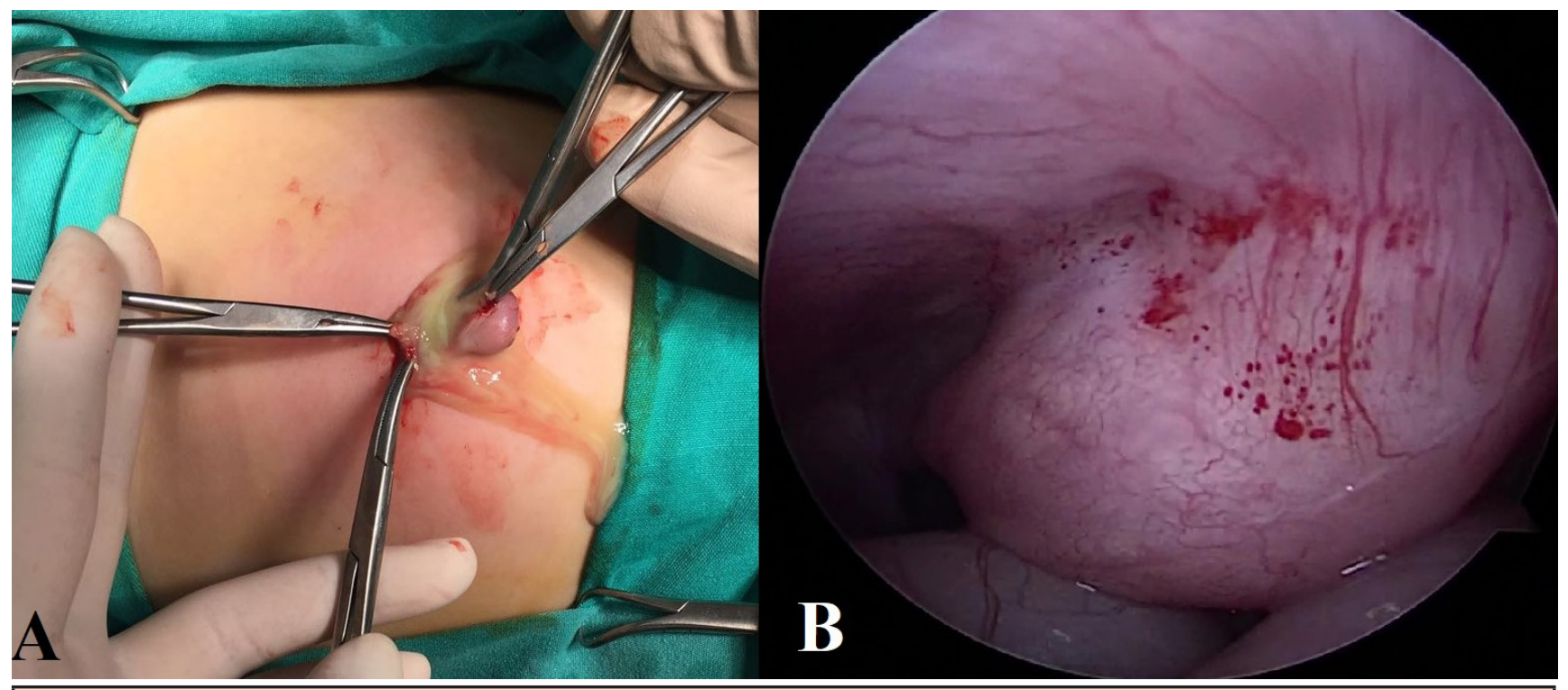

Figure 1: Discharge through the umbilicus in a patient who was referred as incarcerated umbilical herni depending on the ultrasonographic images (A). A $5 \mathrm{~mm}$ camera port was introduced through the Palmer's point and lack of peritoneal violation or contamination was confirmed by direct vision (B).

found between the umbilicus and intestinal mesentery (Figure 3). With the help of a grasper, the band is excised through the second periumbilical port and the patient was free of symptoms 6 months after the operation in the last follow up examination.

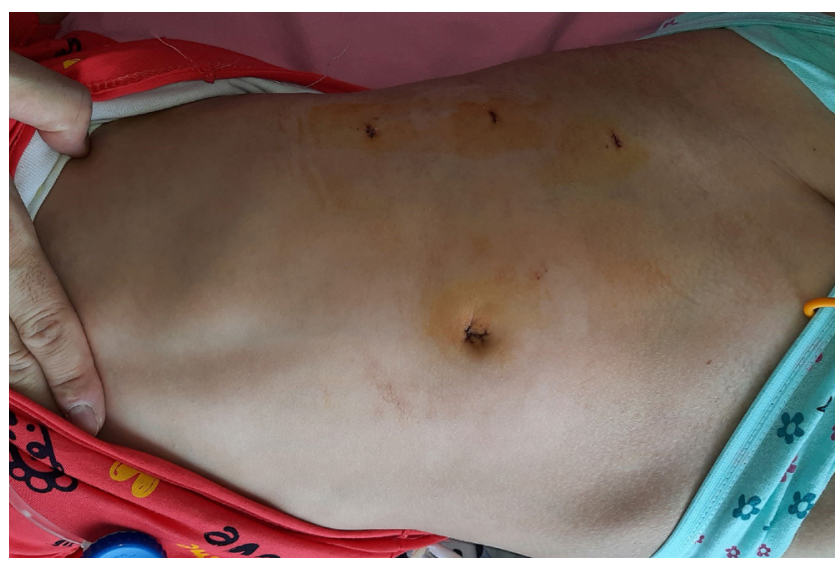

Figure 2: Port sites are demonstrated in a patient who was managed by 4 ports ( 3 left and 1 umbilical).

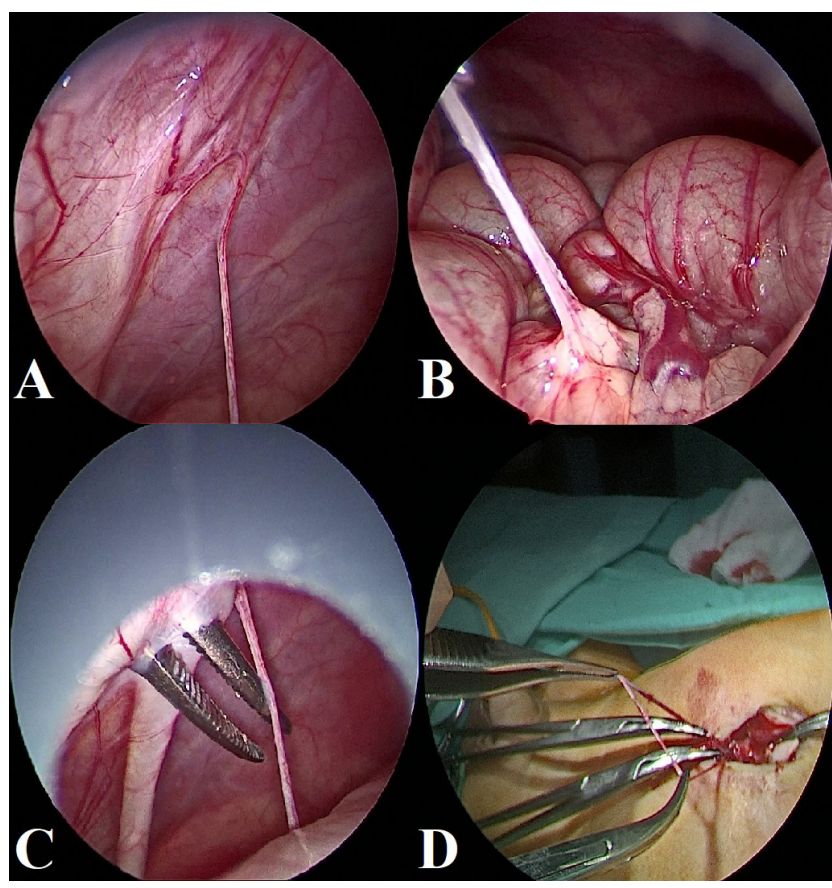

Figure 3: An interesting case of an infant admitted with vague symptoms of umbilical discharge and found to have an omphalomesenteric band between umbilicus and intestinal mesentery. Umbilical end of the band (A). Mesenteric end of the band (B). A mosquito forceps is introduced through a smiling incision $(C)$ and the band is taken out through the incision and excised (D). 


\section{DISCUSSION}

Although still low, the incidence of the urachal conditions is increasing secondary to increased availability of advanced imaging modalities (1). This resulted in increased rate of asymptomatic cases and further questioned the surgical indications of urachal anomalies which are already controversial in children $(2,3)$. Although presence of symptoms is quite a universal indication, relating a symptom with the radiological finding is not always satisfactory. Infection is the most commonly accepted indication for surgery but some still argue in favor of medical management (4). Malignancy is a common concern but it is rarely reported in children and data about the transformation to urachal carcinoma later in life is insufficient.

When a hard decision process that ends with surgical exploration is concluded, the next concern emerges as how to do the exploration. Suprapubic transvers, midline or a periumbilical incisions can be preferred depending on the surgeons experience $(5,6)$. Although suprapubic or periumbilical incisions are cosmetically more acceptable, they may not allow satisfactory evaluation and exploration of the area of interest (area among the umbilicus, bladder dome and median umbilical ligament). On the other hand, a midline incision that provides generous exposure might be "too much" and "not cosmetic" for a benign condition. Although robotic surgery is also described for the correction of urachal anomalies, cost and availability of the robot is a major problem and may be challenging in young children (7).

Identification of the surgical margins may be challenging in a significant number of patients before and during surgery (5). Additionaly, previous infection episodes may result in omental or intestinal adhesions that cause trouble in identifying the tissue margins during surgery. All these concerns may confuse the clinician during the management of urachal anomalies and may sometimes effect the management modality; is the juice worth the squeeze?

The surgery is quite straightforward in urachal cyst and urachal diverticulum but is challenging and may be confusing in patent urachus, umbilical sinus or complicated cases. In acute conditions like infection or abscess, the diagnosis and management is more challenging (8). Complete excision of the urachal tract is recommended whenever possible (9). Umbilectomy may also be recommended in adults or if umbilical involvement can not be ruled out (10). However, the condition is poorly documented in a significant rate of patients due to complications or heterogenous/obscure nature of the anomaly. In this context, laparoscopic approach offers a superior exposure and vision with excellent cosmetic results (11). Especially in complicated cases with abscess or in challenging cases without a definitive diagnosis before surgery, laparoscopy offers detailed documentation of the condition, extent of the disease and involved adjacent structures. After definitive diagnosis is established with the help of the scope, appropriate interventions can be performed in single or multiple sessions.

In one of our patients who presented with fever and vomiting mimicking incarcerated umbilical hernia, definitive diagnosis was established during the operation and the patient was safely managed with good cosmetic results, thanks to the help of the laparoscope. In such cases without a definitive diagnosis, laparoscopy should be encouraged to confirm and treat the condition as mortality has been reported due to a possible delay in diagnosis (12). In the other infant presented with umbilical discharge and had a preoperative diagnosis of patent urachus, no urachal remnant was found but an omphalomesenteric band located between intestinal mesentery and umbilicus which was managed with excellent cosmetic results that has the potential to cause serious complications (intestinal obstruction or volvulus..) later in life if it would gone unnoticed during surgery(Figure 3) (13).

Low risk minor surgeries with cosmetically good results are usually accepted more easily both by patients and physicians. When the potential risks and extent of the surgery increase, both patients and physicians refrain from surgery and indication of the surgery is scrutinised more extensively. Unfortunately, indication of surgery is widely variable in children for urachal anomalies and evidence for malignant transformation is lacking as it's significantly hard to demonstrate the relation between an urachal remnant identified in childhood and an urachal malignancy (which is most commonly seen after the 5th decade) (14, 15). Due to this unclarity, parents and physicians hesitate to proceed with surgery but remain anxious and dissatified. In this context, minimal invasive surgery (laparoscopic or robotic) may provide a more accurate diagnosis, a smoother perioperative course, better cosmetic results, and relief and satisfaction for all the involved parties (16).

\section{CONCLUSION}

Despite the growing bulk of literature about the urachal remnants, significant controversary persist about the definition, classification and management due to low 
incidence of the condition. Laparoscopic or laparoscopyasisted management may provide relief and satisfaction both for the patient and the physician.

\section{DECLARATIONS}

\section{Conflict of interest statement}

The authors declare no conflict of interest related.

\section{Ethical Approval}

Ethical board approval was obtained from Ondokuz Mayıs University Ethical Committe For Human Subjects (Approval number: 2020/502).

\section{REFERENCES}

1. Stopak JK, Azarow KS, Abdessalam SF, Raynor SC, Perry DA, Cusick RA. Trends in surgical management of urachal anomalies. Journal of pediatric surgery 2015;50:1334-7.

2. Upadhyay V, Kukkady A. Urachal remnants: an enigma. European journal of pediatric surgery : official journal of Austrian Association of Pediatric Surgery (et al) $=$ Zeitschrift fur Kinderchirurgie 2003;13:372-6.

3. Ozbek SS, Pourbagher MA, Pourbagher A. Urachal remnants in asymptomatic children: gray-scale and color Doppler sonographic findings. Journal of clinical ultrasound : JCU 2001;29:218-22.

4. Nogueras-Ocaña $M$, Rodríguez-Belmonte $R$, Uberos-Fernández J, Jiménez-Pacheco A, Merino-Salas S, Zuluaga-Gómez A. Urachal anomalies in children: surgical or conservative treatment? Journal of pediatric urology 2014;10:522-6.

5. Hinman's Atlas of Pediatric Urologic Surgery, 2nd edition In: Hinman F BL, editor.: by Saunders, an imprint of Elsevier Inc.; 2019.

6. Chiarenza SF, Scarpa MG, D'Agostino S, Fabbro MA, Novek SJ, Musi L. Laparoscopic excision of urachal cyst in pediatric age: report of three cases and review of the literature. Journal of laparoendoscopic \& advanced surgical techniques Part A 2009;19 Suppl 1:S183-6.

7. Ahmed H, Howe AS, Dyer LL, Fine RG, Gitlin JS, Schlussel RN, et al. Robot-assisted Laparoscopic Urachal Excision in Children. Urology 2017;106:103-6.

8. Luo CC, Huang CS, Wu WC, Chu SM, Chao HC. An unusual presentation of an infected urachal cyst: case report and review of the literature. European journal of pediatrics 2004;163:268-9.

9. luchtman M, Rahav S, Zer M, Mogilner J, Siplovich L. Management of urachal anomalies in children and adults. Urology 1993;42:426-30.

10. Ashley RA, Inman BA, Routh JC, Rohlinger AL, Husmann DA, Kramer SA. Urachal anomalies: a longitudinal study of urachal remnants in children and adults. The Journal of urology 2007;178:1615-8.

11. Okegawa T, Odagane A, Nutahara K, Higashihara E. Laparoscopic management of urachal remnants in adulthood. International journal of urology : official journal of the Japanese Urological Association 2006;13:1466-9.

12. Rich RH, Hardy BE, Filler RM. Surgery for anomalies of the urachus. Journal of pediatric surgery 1983;18:370-2.

13. Moore TC. Omphalomesenteric duct malformations. Seminars in pediatric surgery 1996;5:116-23.

14. Gleason JM, Bowlin PR, Bagli DJ, Lorenzo AJ, Hassouna T, Koyle MA, et al. A comprehensive review of pediatric urachal anomalies and predictive analysis for adult urachal adenocarcinoma. The Journal of urology 2015;193:632-6.
15. Bruins HM, Visser O, Ploeg M, Hulsbergen-van de Kaa CA, Kiemeney LA, Witjes JA. The clinical epidemiology of urachal carcinoma: results of a large, population based study. The Journal of urology 2012;188:1102-7.

16. Osumah TS, Granberg CF, Butaney M, Gearman DJ, Ahmed M, Gargollo PC. Robot-Assisted Laparoscopic Urachal Excision Using Hidden Incision Endoscopic Surgery Technique in Pediatric Patients. Journal of endourology 2021;35:937-43. 